\title{
Analysis of Students' English Reading Comprehension through KWL (Know-Want-Learn) Learning Strategies
}

\author{
Eva Yuni Rahmawati \\ Universitas Indraprasta PGRI Jakarta \\ Email: everez29@gmail.com
}

How to cite this paper: Rahmawati, E. (2018). Analysis of Students' English Reading Comprehension through KWL (KnowWant-Learn) Learning Strategies. International Journal of Language Teaching and Education, 2(3), 238-247. https://doi.org/10.22437/ijolte.v2i3.5641

Accepted: October 18, 2018

Published: November 30, 2018

Copyright (c) International Journal of Language Teaching and Education. This work is licensed under the Creative Commons Attribution InternationalLicense (CC BY 4.0).

http://creativecommons.org/licenses/by/4 (c) †

\begin{abstract}
This research aims to know the reading comprehension of students through KWL learning strategies. The research is descriptive research survey. The subject of research is the student of Mathematics Education Programwho learned English. A sample of this research used Simple Random Sampling technique $(n=40)$. Data collection is done by carrying out a test of reading using the test, after the students being treated by KWL learning strategies. Analysis of research data using descriptive statistical techniques. The results showed that, there are $75 \%$ of the students who were able to determine the topic from the reading passage, $62.5 \%$ of the students were able to determine the word reference and $67.5 \%$ of students were able to determine the main idea of the text and $50 \%$ were able to determine the detail information. It can be concluded that the KWL strategy is able to improve students reading comprehension.
\end{abstract}

Subject Areas

Language Teaching

\section{Keywords}

English Reading Comprehension, Know-Want-Learn Learning Strategies

\section{Introduction}

English is one of the subjects that must be taught at every level of education. In the University, English is taught at the first and second semester for study programs. In other words, we can say English for Special Purposes (ESP). The purpose is to develop the learners communicative competence in a specific discipline. Meanwhile, there are four English skills, namely: listening, speaking, reading and writing.

One of language skill is reading, reading is an important activity to do, because various information can be obtained by reading. Reading is one of the skills that process and receive information. Reading is seen as a channel of language processing, a form of communication between writers and readers who are mediated through a written text (Sulistyo, 2011). The ability in reading English text is not only can read text smoothly, but understand the contents of the text and understand the message from the author. However, the learners still have difficulty in understanding the text. It can be seen from the test results. There are several factors that cause the learners faced the difficulties in understanding the text, such as lack of vocabulary in English, lack of grammatical understanding, and lack of background knowledge. This is in accordance with Tyler's (1994) statement that there are six basic factors that influence 
students' reading comprehension ability: 1) Experience background, 2) Intellectual ability, 3) Language Ability, 4) Interest, 5) Reading Purpose, 6) Skills Reading Understanding.

Reading comprehension ability is the ability to understand the core of a topic. Rubin (1981), states that reading comprehension is a complex thinking process that involves a number of abilities. Therefore, a learning strategy is needed which is expected to help students understand text easily. There are various kinds of learning strategies, but the strategy that is used in this research is KWL (know-want-learn) strategy. The strategy was first developed by Ogle in 1986 on the basis of the idea that language learners gain knowledge by constructing meaning. The KWL strategy was first developed by Ogle in 1986 which is an idea that language learners gain knowledge by forming meaning. This means that the learner can connect the initial knowledge with new information is created.

\section{LiteratureReview}

\subsection{KWL(Know, Want, and Learn) Learning Strategy}

The KWL(Know, Want, and Learn) learning strategy was developed by Ogle in 1986. The aim of this strategy is to facilitate students' metacognitive thinking processes. This strategy can be illustrated by a simple graph consisting of three columns. The first column is labeled "K" which stands for what students already know about the topic. The second or middle column is labeled "W" which stands for what mind students will learn. The third and final columns are labeled "L" which stands for what really isn't learning.

To fill in the "K" column, the lecturer only brainstorms all the different ideas that are in relative knowledge before the topic. Remember the topic is the person, place, or thing the chapter is about. If you find that you have limited prior knowledge about the topic, then the lecturer asks students to find out about topics that can be done in books or the Internet and search by using topics as keywords.

According to Ogle in Abdulrab (2015), the stages of learning using KWL are:

1) Introduce and explain strategies for each student group, or a group of students as a whole.

2) Divide the student activity sheet, which shows three parts by placing $K$ in the first column, $\mathrm{W}$ in the second column, and $\mathrm{L}$ in the third column. Choose a topic and guide students in brainstorming activities to generate ideas about what they already know about the topic, then students will place it in column K. Students to verbally describe to the lecturer's background information on what they have and lecturers then write on the board in column $\mathrm{K}$.

3) Guiding students in generating questions. Use probing questions to encourage students to think. This is information for column $\mathrm{W}$ and students will write these questions in column W. Students must be given text on the topic. They can read the text independently or in small groups. Text must be managed until students become familiar with this technique. Reading the text allows students to realize what they are learning and what they have not understood. 
4) Students read the text and find new information, they can add questions to column W. Students continue through the material, they constantly think about what they read, monitor their learning, and may generate additional questions to guide their reading. When they examine with an eye towards answering their questions have been asked, students must record new information in column $\mathrm{L}$, which identifies what they have learned. Students will record answers to their questions and other information they have learned. In many cases, they also know that what they think they know is inaccurate.

5) Guide students through the process of categorizing information in column K. This allows them to anticipate the information fields they can find in their research. Have students ask themselves what each statement describes. The process of categorizing strategies by thinking hard while identifying categories and combining and classifying information. The KWL strategy is arranged in the following table form:

Table 1. KWL Strategi

NAME:

TOPIC:

K - What WeKnow $\quad$ W - What we want to Learn $\quad$ L-What We Learned

According to Rahim (2008) the advantage of the KWL strategy is that students can set goals and provide an active role before, during, and after reading. The KWL strategy can help them think about the new information they receive. The KWL strategy can also strengthen students' ability to develop questions about various topics. Students can also assess their own learning outcomes. So, through the implementation of the KWL strategy students are expected to be able to understand the contents of a reading without being separated from their active role in linking new knowledge with the knowledge they have acquired beforehand.

From the above concept it can be concluded that the stages in KWL learning are explained in the following table: 
Table 2. Stage in KWL Learning Strategy

\begin{tabular}{ll}
\hline & Learning steps KWL \\
\hline & \multicolumn{1}{c}{ Initial Activities } \\
\hline \multicolumn{1}{c}{ Lecturer } & \multicolumn{1}{c}{ College Student } \\
\hline $\begin{array}{l}\text { Introduce and explain the } \\
\text { strategies for each group } \\
\text { of students }\end{array}$ & $\begin{array}{l}\text { The student explained the explana- } \\
\text { tion of the lecturer }\end{array}$ \\
$\begin{array}{l}\text { Distribute the student } \\
\text { work sheet, which shows } \\
\text { three parts by set down K } \\
\text { in the first column, W in } \\
\text { the second column, and L } \\
\text { in the third column }\end{array}$ & \\
\hline
\end{tabular}

Core Activities

\begin{tabular}{ll} 
K-What We Know & \\
\hline \multicolumn{1}{c}{ Lecturer } & College Student \\
\hline$\circ \quad \begin{array}{l}\text { Guiding students about } \\
\text { what they have already } \\
\text { known about the subject } \\
\text { matter presented }\end{array}$ & \\
Lecturer start by using \\
brainstorming activity to \\
help students organize \\
their ideas
\end{tabular}

W- What We Want to Learn

\begin{tabular}{lll}
\hline \multicolumn{1}{c}{ Lecturer } & \multicolumn{1}{c}{ College Student } \\
\hline$\circ \begin{array}{l}\text { Lecturer help students } \\
\text { fill out column W by dis- } \\
\text { cussing what they want } \\
\text { to learn from the mate- } \\
\text { rial presented }\end{array}$ & $\begin{array}{l}\text { Students write specific questions } \\
\text { where they are more interested in the } \\
\text { subject matter that has been prepared } \\
\text { in Students Work Sheet }\end{array}$ \\
\end{tabular}


Closing Activity

L- What We Learned

\begin{tabular}{lll}
\hline \multicolumn{1}{c}{ Lecturer } & \multicolumn{1}{c}{ College Student } \\
\hline$\circ \quad \begin{array}{l}\text { Lecturer ask students to } \\
\text { write down what they } \\
\text { learned }\end{array}$ & $\begin{array}{l}\text { Students examine the questions that have } \\
\text { been generated }\end{array}$ \\
\hline
\end{tabular}

\subsection{English Reading Comprehension}

Tarigan (2008) reveals that reading is a process carried out to obtain messages, which the writer wishes to convey through the words / written language. Whereas Nation (2009), "reading is a source of learning and a source of enjoyment". According to Broughton quoted Tarigan (2008) reading skills have two important aspects, namely mechanical skills and understanding skills. Understanding skills cover 4 things, namely: 1) understanding simple understanding; 2) understanding the significance / meaning, 3) assessment, 4) flexible reading speed. Mastery of skills that are of this understanding allows the reader to understand the meaning of the words / sentences contained in the reading

Rubin in Somadayo (2011) stated that reading comprehension is a complex intellectual process that includes two main abilities, namely mastery of the meaning of words and the ability to think about verbal concepts. This means that in reading comprehension, simultaneous two-way concentration occurs in the reader's mind in conducting reading activities, the reader actively responds by expressing the writing sound and the language used by the author. Therefore, the reader is required to be able to express the meaning contained in the text that is the meaning that the writer wants to convey.

Razak (2009) points out that reading comprehension is "the ability of the reader to recite the contents of the argumentation, expository, or read a description of a particular topic.Mulyati, et al (2007), "That reading comprehension is a reading activity that is done to get an understanding of something or for learning purposes, so as to gain a broader insight into something that is read.

According to Djiwandono (2008) there are several indicators in understanding a reading that is as follows. Understand the meaning of words according to use in discourse b. Identify the organizational structure of discourse and the relationship between its parts c. Recognize the main points of thoughts expressed in discourse. Able to answer questions whose answers are explicitly contained in the discourse e. Able to answer questions whose answers are contained in discourse even though expressed in different words f. Able to draw inferences about the contents of the discourse g. Able to recognize and understand words and phrases to understand literary 
nuances $\mathrm{h}$. Able to recognize and understand the intent and message of the author as part of an understanding of the author

Somadayo (2011) states that there are three stages in implementing reading comprehension learning activities, namely:

1. Prepaid stage: teaching reading must be based on the view of the schema theory. Based on this theory, effective lecturers must direct students to use topic knowledge to get ideas and messages of a text. Guber in Farida (2005) states that there are several techniques that can be done to activate student schemes through pre-reading activities. The intended privacy activity is to make predictions as follows: the lecturer reads the reading title and then introduces it to the student, predicts activities to tell the student's interest in the reading, and uses various stimuli to maintain the student's attention to the reading.

2. Reading Activities stage. In reading activities the lecturer discuss with the learners about what are they going to learn from text. This is so that students can predict answers to questions in accordance with the purpose of reading and testing the accuracy of their predictions, compiling questions to test information obtained and working in groups / individuals, and making reading summaries.

3. Post-reading stage Post-reading activities can be developed in the following ways: Students are given the opportunity to find further information about the topic, students are given feedback with questions about the content of the reading, students are given the opportunity to organize the material to be presented and students are given the opportunity to do assignments to improve understanding

\section{Method}

This study was carried out on students of the Mathematics Education Study Program who studied English language lectures. The research method used a descriptive survey. According to Nasir (2005) descriptive survey is "a method of examining the status of a group of people, an object, a condition, a system of thought or a class of events in the present which aims to create a systematic, factual and accurate description, picture or painting of facts -facts, traits and relationships between phenomena investigated. The population of this study were the students of the second semester in mathematics education program study who studied English, with a total sample is 40 students. Sample was taken by simple random sampling technique. Data collection results is reading comprehension test after being treated by KWL strategy. Data analysis techniques used descriptive statistics consisting of mean, median and frequency mode and analysis.

\section{Findings and Discussions}

\subsection{Findings}

The results of reading comprehension test of students who were treated with KWL learning strategies (know-want-learn) obtained the following results: number of 
respondents 40 students, minimum score is 50 , maximum score is 90 , the range of empirical scores were 91-50 $=41$, and the theoritical range of 0-100. Furthermore, the data is presented in a table of a frequency distribution with the number of six class, the widht of interval class is 7 , the average score is 69.00 , mode 66.5 , median is 67.5 and standard deviation is 10.21 .

The score of reading comprehension of students who were treated with KWL learning strategies (know, want, learn), shows that there are 12 (30\%) students under the interval class which contains an average score, 14 (35\%) students are in the interval class which contains an average score and 14 (35\%) students are above the interval class which contains the average score. Based on the data above it can be said that students who have scores above the average score are more than students who have scores below the average.

To clarify the reading comprehension data of students who were treated with KWL learning strategies (know, want, learn), it is presented with the following histogram display.

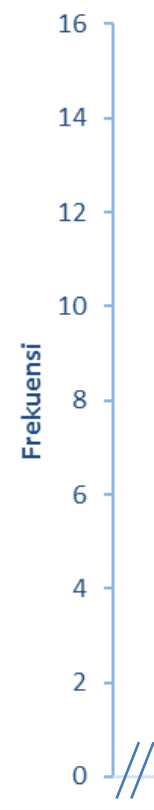

Figure 1 Understanding Score Histogram Reading Students Given a KW Learning Strategy

While the analysis of reading comprehension test results with indicators 1) Determine the main topic or theme of reading, 2) reference, 3) Conclusion, and 4) detail information, presented in the table below: 


\begin{tabular}{cccccccc}
\hline \multicolumn{7}{c}{ Indicators of reading comprehension } \\
\hline topic & & reference & & Conclusion & $\begin{array}{l}\text { detail } \\
\text { mattion }\end{array}$ & infor- \\
\hline Fn & $\%$ & Fn & $\%$ & Fn & $\%$ & Fn & $\%$ \\
30 & 75 & 25 & 62,5 & 27 & 67,5 & 20 & 50 \\
30 & 75 & 25 & 62,5 & 27 & 67,5 & 20 & 50 \\
\hline
\end{tabular}

Based on the table above it can be explained that in the text item reading comprehension there are $75 \%$ of students who are able to solve the problem at the stage of determining the main topic or theme of reading, $62.5 \%$ of students who are only able to solve the problem at the stage of determining the reference word and $67.5 \%$ capable students at the stage determine the conclusions of the reading and $50 \%$ determine the detailed information.Based on the results of the data analysis above it can be said that learning using KWL learning strategies can help students understand reading. This can be seen from the results of each student reading indicator above or equal to $50 \%$.

\subsection{Discussion}

Indicators of reading comprehension measurement consist of four stages, namely: 1) Determine the main topic or theme of reading, 2) Determine the reference word, 3) Determine the conclusion of the reading, and 4) Determine the detailed information. The results showed that in text item reading comprehension there were $75 \%$ of students who were able to solve the problem at the stage of determining the main topic or theme of reading, $62.5 \%$ of students who were only able to solve the problem at the stage of determining the reference word and $67.5 \%$ of students who were able at the stage of determining the conclusion of the reading and $50 \%$ determining the detailed information.

Based on these results, the KWL learning strategy is able to improve student reading comprehension. Through the implementation of the KWL learning strategy, students become more active and independent in carrying out the assignments. In addition, the learning atmosphere during learning activities seems fun, provokes curiosity, and motivates students. This is because the KWL learning strategy requires students to be more independent in thinking, as in the first step to explore students' initial knowledge about what is known, the second step requires students to develop curiosity about what they want to know, and the final step is to read and gain knowledge. and more insight into the topic. This makes students more interested in learning to read.

KWL learning strategy is able to increase students 'reading interest, this is in accordance with Ogle (1986) KWL strategy to help lecturers turn on the background of students' knowledge and interests on a topic. The KWL strategy gives students the purpose of reading and provides an active role for students before, during, and after reading. This strategy helps them think about the new information they receive. This 
strategy can also strengthen students' ability to develop questions about various topics. Students can also assess their own learning outcomes. On the other hand According to Rahim (2008), the advantage of the KWL strategy is that students can set goals and provide an active role before, during, and after reading.

The results of this study are supported by several previous studies that was conducted by Riswanto (2014) revealing that the KWL strategy is effective in increasing students' reading comprehension. Its effectiveness is indicated by the results of the regression that the KWL contribution to the strategy of student reading ability is $70.5 \%$. Research conducted by Dieu. (2015) shows that "As a result, the research has proved the effectiveness of the treatment. It is also suggested how to control a reading class, to create an interesting and exciting atmosphere to improve students' reading comprehension skill ", this study proves the influence of K-W-L Strategy on teaching reading comprehension. This also proves a way to control reading classes, to create an interesting and fun atmosphere to increase students' reading comprehension skills

KWL learning strategies, students are given the opportunity to find and solve a problem on their own. KWL learning strategies are specific strategies of metacognitive approaches that promote effectiveness and efficiency in thinking and problemsolving. Lecturers facilitate effective thinking and problem-solving. Effective problem solving must begin with identifying potential difficulties which will then be followed by problem identification. Students take action on their own solutions. Generally students who have enough competence will plan for their thinking process, through reflection and open-mindedness in finding solutions. Finally, after finding a solution, note the student on what is needed to get the optimal solution.

\section{Conclusion}

Based on the results of the data analysis and discussion that mentioned above, it can be concluded that KWL learning strategies are able to improve students' reading comprehension. Some suggestions are given to lecturers and fellow researchers who will develop and improve the quality of research with similar or similar topics, so there are some things that can be considered as follows: (1) Students as individuals initially have a high reading interest, but if one uses a learning strategy will have an impact on the results of reading it. Because with KWL, lecturers need to be considered as an alternative to teaching students in reading comprehension; (2) Lecturers as the most important element in the learning process must strive to display learning processes that can facilitate diverse students; (3) Creating a learning process that can develop the independence of student learning; (4) For the next researcher who will research and develop on the same topic, it is expected to be able to make a more specific measurement tool and a simpler language so that it is easy for students to understand. 


\section{References}

[1] Sulistyo, G.H. (2011). Reading for Meaning. Malang: PustakaKaiswaran

[2] Tyler, R. (1994). Children Construction of Explanation in Science. Victoria: Deakin University

[3] Rubin, D. (1983). Writing and Reading The Vital Arts. New York: Mcmillan Publishing Co., Inc.

[4] Abdulrab,A. H. M., (2015) "Effectiveness Of KWL-Plus Strategy On Acquisition The Concepts In Science And Attitude Towards Science For Eighth Grade Students.” International Journal of Innovative Research and Studies, Vol. 4 (3)

[5] Rahim, F. (2008). PengajaranMembaca di Sekolah Dasar. Jakarta :BumiAksara.

[6] Tarigan, H. G. (2008). Membaca: sebagaiSuatuKeterampilanBerbahasa. Bandung: Angkasa.

[7] Nation, S. P. (2009). Teaching ESL/EFL Reading and Writing. New York. Routledge

[8] Tarigan, H. G. (2008). Membaca: sebagaiSuatuKeterampilanBerbahasa. Bandung: Angkasa

[9] Somadaya, S. (2011). Strategidan Teknik PembelajaranMembaca. Yogyakarta: GrahaIlmu.

[10] Razak, A. (2005). MembacaPemahamanteoridanAplikasiPengajaran. Pekanbaru:Autobiografi

[11] Mulyati, Y.dkk. (2007). KeterampilanBerbahasa Indonesia SD. Jakarta :Universitas Terbuka

[12] Djiwandono,S. (2008). Tes Bahasa. Jakarta: PT Indeks

[13] Somadaya, S. (2011). Strategidan Teknik PembelajaranMembaca. Yogyakarta: GrahaIlmu.

[14] Nazir, M. (2005). MetodePenelitian . Jakarta: PT Ghalia Indonesia

[15] Ogle, D. (1986) K-W-L: A Teaching Model That Develops Active Reading of Expository Text. The Reading Teacher, 39, 564-570. http://dx.doi.org/10.1598/RT.39.6.11

[16] Rahim, F. (2008). PengajaranMembaca di Sekolah Dasar. Jakarta :BumiAksara

[17] Riswanto., Risnawati., Deti,.(2014). The Effect of Using KWL (Know, Want, Learned) Strategy on EFL Students' Reading Comprehension Achievement. International Journal of Humanities and Social Science. Vol. 4, No. 7(1)

[18] Dieu, Tran Thi Thanh. (2015). Trying K-W-L Strategy on Teaching Reading Comprehension to Passive Students in Vietnam. International Journal of Language and Linguistics. Vol. 3, No. 6, 2015, pp. 481-492. 